\title{
Giant cell tumor of tendon sheath
}

\author{
Abhishek Singh ${ }^{1}$, Nagendra Yadav ${ }^{1 *}$, Bharat Bhushan Dogra1, Ashutosh Singh ${ }^{2}$
}

${ }^{1}$ Department of Surgery, Dr. D. Y. Patil Medical College, Pune, Maharashtra, India

${ }^{2}$ Department of Orthopaedics, Dr. D. Y. Patil Medical College, Pune, Maharashtra, India

Received: 18 August 2017

Accepted: 21 September 2017

*Correspondence:

Dr. Nagendra Yadav,

E-mail: Naguyadav47@gmail.com

Copyright: ( ) the author(s), publisher and licensee Medip Academy. This is an open-access article distributed under the terms of the Creative Commons Attribution Non-Commercial License, which permits unrestricted non-commercial use, distribution, and reproduction in any medium, provided the original work is properly cited.

\begin{abstract}
Giant Cell Tumor of Tendon Sheath (GCTTS) is the second most common benign tumour affecting hand after ganglion. The tumor generally affects individuals between the age of 30 and 50 years, and is found more often in women than men. The etiological factors responsible for GCTTS are unclear. Some authors consider it as an inflammatory process arising as a consequence of chronic antigenic stimulation. Local excision with or without radiotherapy is the treatment of choice. We recently encountered two cases of Giant cell tumor involving tendon sheath of ring finger in one case and thumb in another case. Both were managed surgically with good results. There has been no evidence of recurrence till date in the follow up varying from 3-6 months.
\end{abstract}

Keywords: Flexor tendon, Giant cell tumor, Tendon sheath

\section{INTRODUCTION}

Giant cell tumor of tendon sheath (GCTTS) is an uncommon benign tumor of the hand commonest being Ganglion cyst. ${ }^{1}$ Generally, it presents itself as a subcutaneous nodule over the hand, but occasionally it may involve other parts of the body as well, such as the spine, ankle, knee and feet. ${ }^{2}$ Overall incidence in general populations is $1 / 50,000$.

However, the incidence of GCTTS is higher in women than in men and is mostly seen in the third to fifth decade. $^{3}$ The etiology of giant cell tumor of the tendon sheath remains unclear. Various theories held responsible for this disease are trauma, disturbed lipid metabolism, osteoclastic proliferation, infection, vascular disturbances, immune mechanisms, inflammation, neoplasia, and metabolic disturbances. ${ }^{4}$ Probably the most widely accepted theory, as proposed by Jaffe et al, is that of a reactive or regenerative hyperplasia associated with an inflammatory process, developing from the synovial lining of the tendon sheath. ${ }^{5}$ A high mitotic rate is thought to be indicative of local recurrence.

\section{CASE REPORT}

Case 1

AB, 25-year-old female, presented with a painless swelling over working surface of her right ring finger of one-year duration. Swelling gradually increased in size. Patient denied history of local trauma or any restriction of movements. Clinically, there was a well-defined lobulated swelling on volar aspect of right ring finger involving its middle third, extending distally upto interphalangeal joint and dorsally across its radial border (Figure 1). Swelling was firm in consistency and nontender. It was not fixed to bone nor did it move on movements of finger.

X-ray Ring finger excluded any bony abnormality and Ultrasound of the swelling showed it to be a solid, homogenous, hypoechoic mass, adjacent to insertion of flexor digitorum sublimus tendon. Fine Needle Aspiration Cytology (FNAC) reported features suggestive of inflammatory lesion (Figure 2). 


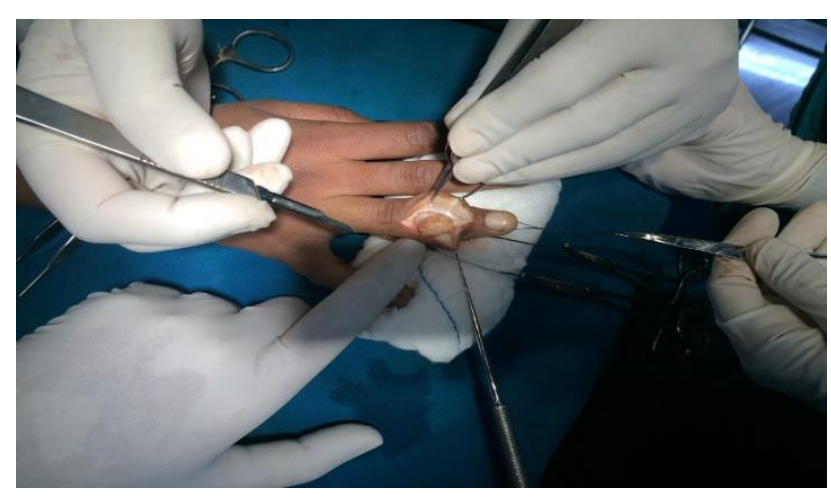

Figure 1: Giant cell tumor of tendon sheath.

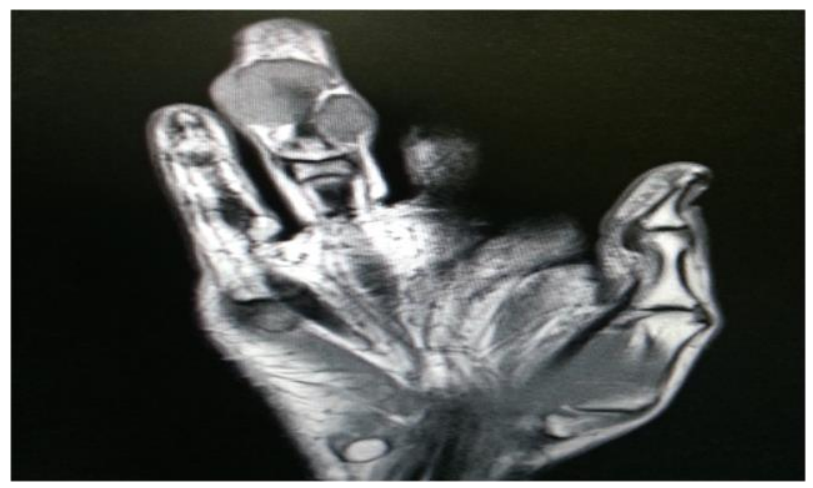

Figure 2: X-ray of right ring finger tumor.

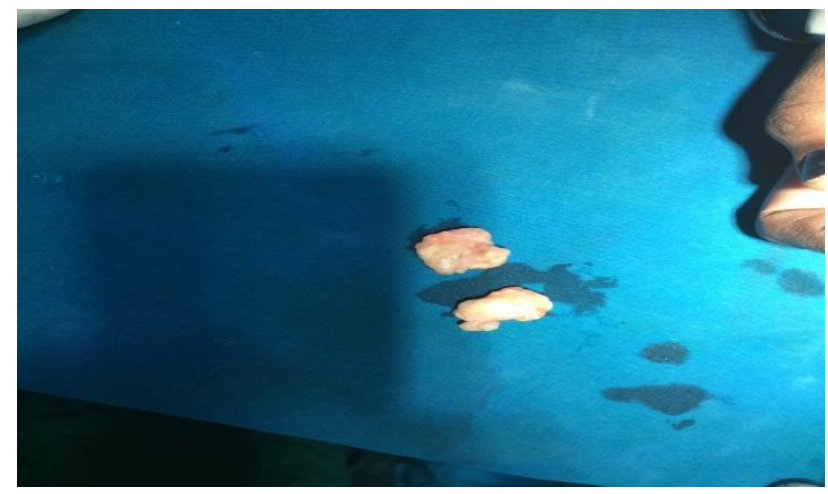

Figure 3: Specimen of resected tumor.

MRI however, confirmed the mass to be a soft tissue lesion over ventero-lateral aspect of middle and distal phalanx region of ring finger, causing circumferential encasement of flexor digitorum sublimus tendon with its cranio-caudal extension of $28 \mathrm{~mm}$, without any evidence of bony erosion/destruction (Figure 3). She was diagnosed as a case of Giant cell tumor of tendon sheath (GCTTS) of Flexor digitorum sublimus (FDS) tendon and taken up for excision under $\mathrm{GA}$ and tourniquet control. Exploration revealed mass arising from tendon sheath and FDS tendon was free. Tumor was excised preserving the FDS tendon. Histopath exam of excised tissue showed closely packed polyhedral cells with moderate cellularity comprising of few dispersed plump fibro-histiocytic cells and variable number of osteoclast like multinucleated giant cells confirming the diagnosis of teno synovial giant cell tumor (Figure 4). She has been followed up for o6 months post-surgery without any evidence of recurrence.

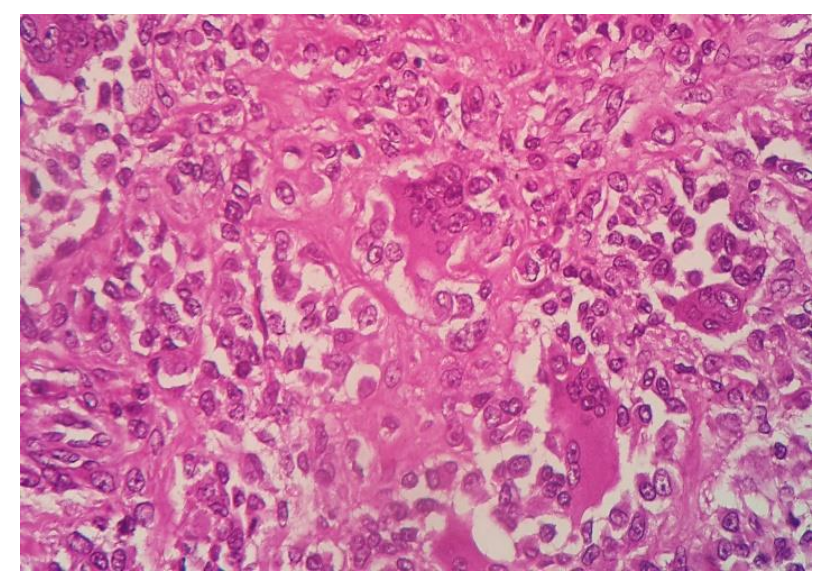

Figure 4: Histopathology of giant cell tumor of tendon sheath.

Case 2

SD, 65 years old lady presented with a painless swelling over her left thumb of 03 years duration, following a blunt trauma when her thumb got entrapped in the door. Clinically, she had $3 \times 2 \mathrm{cms}$ firm, nodular, painless swelling over volar surface of thumb extending dorsoradially. X-ray of thumb excluded any bony pathology and MRI confirmed the swelling arising from Tendon sheath. FNAC of the mass revealed polymorphous population of mononuclear histiocytes, hemosiderin laden macrophages and osteoclast like multinucleate giant cells suggestive of Giant cell tumor of tendon sheath. Complete surgical excision was carried out along with a sleeve of tendon sheath of Flexor pollicis longus (FPL) tendon. Digital neurovascular bundle on the radial aspect of thumb was found to be stretched over the mass which was gently dissected away and preserved. Patient made uneventful post op recovery and has been followed up for 03 months without any recurrence.

\section{DISCUSSION}

Giant cell tumor of the tendon sheath is a relatively rare tumour which may arise from tendon sheath of the hand. GCTTS affects individuals between 30 to 50 years of age and is seen more oftenly in women than in men Monaghan et.al in his series of 71 cases of GCTTS noted mean age of his patients as 46.3 years with a peak incidence in $4^{\text {th }}$ decade. ${ }^{3}$ However, one of the cases being reported here was 25 years female and other lady was 65 years old.

Most of the lesions in the hand are seen involving right hand affecting index, middle and ring fingers, suggesting that trauma may be the predisposing factor. One of our 
patients attributed her swelling to trauma, when her

thumb got entrapped in a door, 03 years earlier.

Table 1: Anatomic location of giant cell tumor of the tendon sheath.

\begin{tabular}{|llllllll|} 
& Thumb & $\begin{array}{c}\text { Index } \\
\text { finger }\end{array}$ & Long finger & Ring finger & Small finger & $\begin{array}{l}\text { Palm, wrist, or } \\
\text { dorsum of hand }\end{array}$ & Total \\
\hline AL Qattan & 1 & 15 & 15 & 4 & 8 & 0 & 43 \\
\hline Darwish and Haddad & 19 & 10 & 5 & 5 & 7 & 5 & 51 \\
\hline Garg and Kotwal & 14 & 28 & 18 & 36 & 6 & 4 & 106 \\
\hline Jones et a & 15 & 24 & 20 & 12 & 20 & 0 & 91 \\
\hline Kotwal et al & 4 & 16 & 10 & 12 & 4 & 2 & 48 \\
\hline Middleton et al & 4 & 3 & 1 & 3 & 1 & 0 & 12 \\
\hline Phalen et al & 7 & 12 & 18 & 11 & 7 & 2 & 57 \\
\hline Reilly et al & 21 & 27 & 21 & 21 & 17 & 0 & 107 \\
\hline Rodrigues et al & 5 & 7 & 2 & 2 & 1 & 1 & 18 \\
\hline Uriburu and Levy & 4 & 3 & 1 & 3 & 4 & 0 & 164 \\
\hline Ushijima et al & 37 & 38 & 37 & 23 & 23 & 6 & 57 \\
\hline Wright & 12 & 10 & 11 & 5 & 6 & 13 & 65 \\
\hline Current study & 11 & 24 & 17 & 7 & 5 & 1 & 834 \\
\hline Total & 154 & 217 & 176 & 144 & 109 & 34 & \\
\hline Percentage & $18.5 \%$ & $26.0 \%$ & $21.1 \%$ & $17.3 \%$ & $13.1 \%$ & $4.1 \%$ & \\
\hline
\end{tabular}

These patients generally present as painless swelling over hand, but when it affects other anatomical sites, it may be painful on presentation. ${ }^{6}$ Ultrasonography of the mass is the primary diagnostic tool. GCTTS appears as a solid homogeneous hypoechoic mass on ultrasound exam. It can provide useful information about the tumour vascularity, size and its relationship with the surrounding structures. ${ }^{7}$ However, Magnetic resonance (MR) imaging remains the most conclusive preoperative tool to diagnose GCTTS. Characteristic features being low signal intensity $\mathrm{T} 1-$ and $\mathrm{T} 2$-weighted images, equal to that of skeletal muscle.8 MR imaging can accurately assess the tumour size and degree of extent around the phalanx, which can help in deciding the surgical approach. ${ }^{9}$ Fine needle aspiration biopsy is used to clinch the tissue diagnosis preoperatively.

Treatment of GCTTS is primarily surgery. Most authors agree that the best way to avoid recurrence is to perform complete surgical excision. ${ }^{10}$ GCTTS, on exploration may reveal extensions that go around and under several structures including the neurovascular bundle and it may be the reason for the high recurrence rate. Surgical incisions should be planned in such a way that allows the surgeon to reach the tumour extensions both dorsally and ventrally. The tumour itself must be dissected gently without allowing any seedling, and one should not hesitate to remove a cuff of tendon sheath, part of a capsule, periosteum or even part of a tendon, to make sure that all pathological tissue is removed.

All patients should be warned about possible complications, such as high recurrence rate, numbness, joint stiffness, painful scar and skin necrosis. Pathologists continue to debate whether it is neoplastic or nonneoplastic, what are its morphological and ultrastructural features, its relation with pigmented villo-nodular synovitis, fibroma, and giant cell tumour of the bone. ${ }^{11}$

Surgery alone in GCTTS has a high recurrence rate, which could be as high as $30 \%$. The risk factors which are associated with the high recurrence rate include, proximity to the arthritic joint, proximity to the distal interphalangeal joint of the fingers, proximity to the interphalangealjoint of the thumb, and radiological osseous erosions. ${ }^{12}$ This finding may be because of inherent difficulty of adequately excising the tumor distally at the IP and DIP joint levels, where the neurovascular structures are quite close to tumor.

Kotwal et al recommended postoperative radiotherapy in dosage of $20 \mathrm{~Gy}$ in divided doses of $2 \mathrm{~Gy}$ in cases where complete excision was not possible or in cases where presence of mitotic figures and bone involvement was found. In their study, recurrence rate following this protocol was $0 \% .^{13}$ Coroneos et.al in a review of 58 patients with GCTTS in the hand, found infiltrative disease in 14 patients. Out of these14 patients, 10 received radiation therapy in a dose of $48 \mathrm{~Gy}$ in 24 fractions and at 3.1 years' follow-up, none of the 10 patients treated with radiation therapy had recurrence. ${ }^{14}$

\section{CONCLUSION}

Giant cell tumors are generally benign lesions presenting as painless, gradually progressing mass lesions on the working surface of digits. USG and MR exam will help 
in establishing the diagnosis which can be confirmed by FNAC.

Every effort must be made to reach a preoperative diagnosis to execute the surgery in a manner that complete excision of the lesion is carried out without leaving any seedling. If required one should not hesitate to excise a sleeve of tendon sheath so that excision is not compromised. Every effort must be made to preserve the neurovascular bundle. Patient may be given the benefit of Radiotherapy if the excised specimen shows evidence of mitosis or if excision is less than complete.

\section{Funding: No funding sources}

Conflict of interest: None declared

Ethical approval: Not required

\section{REFERENCES}

1. Fotiadis E, Papadopoulos A, Svarnas T, Akritopoulos P, Sachinis NP, Chalidis BE. Giant cell tumour of tendon sheath of the digits. A systematic review: Hand (New York, NY). 2011;6(3):244-9.

2. Ushijima M, Hashimoto H, Tsuneyoshi M, Enjoji M. Giant cell tumor of the tendon sheath (nodular tenosynovitis). A study of 207 cases to compare the large joint group with the common digit group. Cancer. 1986;57:875-84.

3. Monaghan H, Salter DM, Al-Nafussi A. Giant cell tumour of tendon sheath (localised nodular tenosynovitis) clinicopathological features of 71 cases: J Clin Pathol. 2001;54:404-7.

4. Hosaka M, Hatori M, Smith R, Kokubun S. Giant cell formation through fusion of cells derived from a human giant cell tumor of tendon sheath: J Orthop Sci. 2004;9(6):581-4.

5. Jaffe HL, Lichtenstein HL, Elsutro CJ. Pigmented villonodular synovitis, bursitis, and tenosynovitis. Arch Pathol. 1941;31:731-65.

6. Rao AS, Vigorita VJ. Pigmented villonodularsynovitis (giant cell tumor of the tendon sheath of the synovial membrane). A review of eighty one cases. J Bone Joint Surg Am. 1984;66:76-94.

7. Middleton WD, Patel V, Teefy SA, Boyer MI. Giant cell tumor of the tendon sheath: analysis of sonographic findings. Am J Roentgenol. 2004;183:337-9.

8. Peh WC, Truong NP, Totty WG, Gilula LA. Pictorial review: magnetic resonance imaging of benign soft tissue masses of the hand and wrist. Clin Radiol. 1995;50:519-25.

9. Kitagawa $\mathrm{Y}$, Ito H, Amano Y, Sawaizumi T, Takeuchi T. MR imaging for preoperative diagnosis and assessment of local tumor extent on localized giant cell tumor of tendon sheath. Skeletal Radiol. 2003;32:633-8.

10. Rodrigues C, Desai S, Chinoy R. Giant cell tumor of the tendon sheath: a retrospective study of 28 cases. J Surg Oncol. 1998;68:100-3.

11. Kuhnen C, Muller KM, Rabstein S, Kasprzynski A, Herter P. Tenosynovial giant cell tumor. Pathologe. 2005;26:96-110.

12. Reilly KE, Stern PJ, Dale JA. Recurrent giant cell tumors of the tendon sheath. J Hand Surg [Am]. 1999;24:1298-302.

13. Kotwal PP, Gupta V, Malhtra R. Giant cell tumor of tendon sheath. Is radiotherapy indicated to prevent recurrence after surgery? J Bone Joint Surg Br. 2000;82:571-3.

Coroneos CJ, O'Sullivan B, Ferguson PC, Chung PW, Anastakis DJ. Radiation therapy for infiltrative giant cell tumor of the tendon sheath. J Hand Surg Am. 2012;37(4):775-82.

Cite this article as: Singh A, Yadav N, Dogra BB, Singh A. Giant cell tumor of tendon sheath. Int Surg J 2017;4:3785-8. 